Int. J. Electrochem. Sci., 11 (2016) 5416 - 5426

International Journal of

ELECTROCHEMICAL

SCIENCE

Www.electrochemsci.org

\title{
Highly Sensitive Amperometric Sensor for the Determination of Glucose at Histidine Stabilized Copper Nanospheres Decorated Multi-Walled Carbon Nanotubes
}

\author{
Shen-Ming Chen ${ }^{1,}{ }^{*}$, Rajkumar Devasenathipathy ${ }^{1,2}$, Sea-Fue Wang $^{2,},{ }^{*}$, Karuppasamy Kohilarani $^{2}$ \\ ${ }^{1}$ Electroanalysis and Bioelectrochemistry Lab, Department of Chemical Engineering and \\ Biotechnology, National Taipei University of Technology, No. 1, Section 3, Chung-Hsiao East Road, \\ Taipei 106, Taiwan, ROC. \\ ${ }^{2}$ Department of Materials and Mineral Resources Engineering, No. 1, Sec. 3, Chung-Hsiao East Rd., \\ National Taipei University of Technology, Taipei, Taiwan \\ *E-mail: smchen78@ms15.hinet.net, sfwang@ntut.edu.tw
}

doi: $10.20964 / 2016.07 .62$

Received: 13 March 2016 / Accepted: 11 May 2016 / Published: 4 June 2016

Uniform sized copper nanospheres (CuNSs) were deposited at functionalised multiwalled carbon nanotubes (f-MWCNTs) modified glassy carbon electrode (GCE) through a simple electrochemical method. Here, biomolecule (histidine) is used as stabilizing agent for the synthesis of copper nanospheres. The prepared nanocomposite was characterized by scanning electron microscopy (SEM), Energy-dispersive X-ray spectroscopy (EDX) and X-ray diffraction spectroscopy (XRD). The fMWCNTs/CuNSs modified GCE exhibited a good electrocatalytic activity towards the determination of glucose. Our sensor showed a wide linear range from $10 \mu \mathrm{M}$ to $6910 \mu \mathrm{M}$ with LOD of $1.53 \mu \mathrm{M}$ towards glucose. The sensitivity of our sensor is $1.39 \mu \mathrm{A \mu M}^{-1} \mathrm{~cm}^{-2}$. In addition, the sensor attained an appreciable stability, repeatability and reproducibility. Practicality of our sensor was demonstrated in the human serum samples. Simplicity, biocompatibility, cost effectiveness, and highly stability of electrode surface are the main advantages our fabricated modified electrode.

Keywords: Copper nanospheres, histidine, MWCNTs, glucose, practicality.

\section{$\underline{\text { FULL TEXT }}$}

(C) 2016 The Authors. Published by ESG (www.electrochemsci.org). This article is an open access article distributed under the terms and conditions of the Creative Commons Attribution license (http://creativecommons.org/licenses/by/4.0/). 